\title{
ETIQUETTE, E-ETIQUETTE AND CELL PHONE USE IN THE CLASSROOM
}

\author{
Azad I. Ali, Indiana University of Pennsylvania, azad.ali@iup.edu
}

\begin{abstract}
The use of cell phone has brought many advantages to the society at large. It simplified communications and made it possible to send/receive calls from virtually anywhere or at any time. However, with the use of cell phone, a number of disadvantages have emerged. One of which is the use of cell phone in places that are deemed unacceptable or inappropriate. Among the places that are deemed inappropriate is the classroom. To many, using cell phones in the classroom while a lecture is going on is considered distracting, rude, offensive or just simply inappropriate.

Initial efforts to deal with cell phone use in the classroom focused on banning their use all together. Subsequent surge in the use of cell phones made this proposal impractical and often impossible to enforce. Advances in the technology added more capabilities to cell phones and some experts are advocating using them in the classroom for educational purposes. The author's opinion is that while disbanding the use of cell phone in the classroom is impractical; a better approach is to teach the students the etiquette of using cell phone in the classroom. This paper elaborates on the idea of teaching the etiquette of using cell phones in the classroom.
\end{abstract}

Keywords: Cell phone use in classroom, etiquette of cell phone use in the classroom, teaching of cell phone etiquette and e-etiquette of cell phone use in the classroom

\section{INTRODUCTION}

Cell phones use has become so ubiquitous that we seem to have forgotten that taking or placing a cellular call isn't always okay. People place and take calls in the theater during a performance, in meetings and classes, in the hospital, and in the middle of conversations we're trying to have with them. Have these handy devices become an actual necessity or are they just one more way for us to be rude to each other?

Without a doubt, cell phones do serve invaluable functions. It's great to be able to let someone know that you're stuck in traffic and will be late for meeting. And they can be a lifesaver when we are in unfamiliar surroundings, having car trouble, or confronting emergency. With a cell phone in hand, we're in touch and in control [11, P.52].

The use of cell phones brought so many advantages to humans individually and to society at large that it became an indispensable tool in many cases. The increasing capabilities of cell/smart phone made us individually and collectively more dependent on this device. However, with these kinds of advantages a number of inappropriate uses of cell phones have emerged. Among the places that cell phone use deemed inappropriate is in the classroom and especially while a lecture is going on. The two figures below are downloaded from Google web site depicts typical inappropriate use of cell phones in the classroom. 


\section{Issues in Information Systems}

Volume 14, Issue 2, pp.452-462, 2013

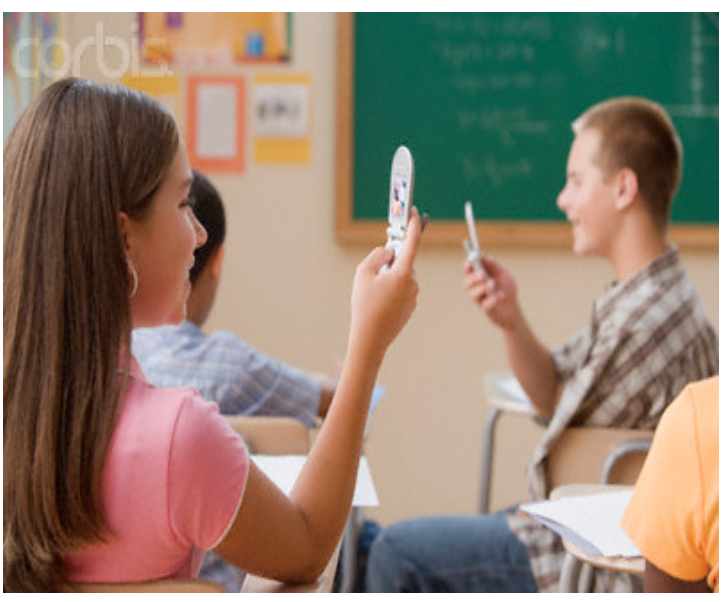

Figure 1 - Cell Phone Use in Classroom 1

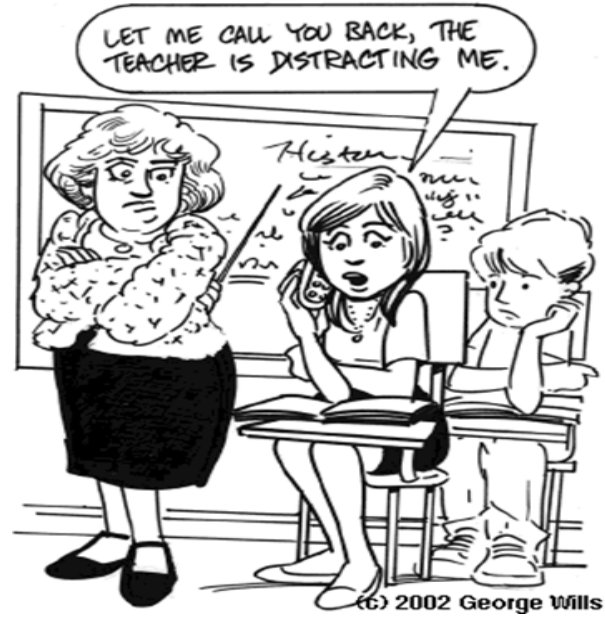

Figure 2 - Cell phone use in classroom 1

Figure 1 shows students openly using cell phones in the classroom. The implicit meaning from second figure is that the students feel they have inherited right to using the cell phone even in the classroom over the teacher's objection. The increasing capabilities of cell phone made them essential tool that cannot be banned at almost any place or setting. Therefore, a moderate solution may involve teaching the students the appropriate use of cell phones in the classroom.

\section{The Case for This Study}

The case for writing this paper can be made in the following points:

- Cell phone use has become an essential communication tool in society

- At the same time, it has been used in inappropriate places such as the classroom

- Cell phone use cannot be banned from the classroom because some students use them for emergency purposes, for keeping appointments and other educational purposes

- At the same time, cell phones can be used as valuable instructional tool in the classroom

- A better approach would be to teach students the appropriate and inappropriate use of cell phones in the classroom. This is termed as etiquette of cell phone use.

\section{Study Outline}

The remainder of this paper is divided into the following sections.

- Section 1 explains about etiquette, e-etiquette the development and the teaching of it

- $\quad$ Section 2 discusses the improper use of cell phones and their distracting effects.

- Section 3 explains the practical use of cell phones for academic and learning purposes.

- Section 4 elaborates on the experience of one faculty in teaching the etiquette of cell phone use in the classroom..

\section{ABOUT ETIQUETTE AND E-ETIQUETTE}

This section explains about two terms: Etiquette and E-Etiquette. It clarifies the meaning and definition of each, it sheds light on how they are developed, and their importance. It also answers the question on whether etiquette of cell phone should be taught or left to the students to learn through experience.

\section{Etiquette - Meaning of}




\section{Issues in Information Systems}

Volume 14, Issue 2, pp.452-462, 2013

Webster's dictionary defined Etiquette as "the conduct or procedure required by good breeding or prescribed by authority to be observed in social or official life". It cited the following examples of using the word in sentences "Her failure to respond to the invitation was a serious breach of etiquette" and "the couple exhibited poor etiquette when they left the party without saying good-bye to the host and hostess". The same dictionary also used the synonyms "manner, form, mores, proprieties" for the same word.

Dissecting the definition further reveals a few components; first good breeding requires it. This may mean good habit, good culture and good form of conduct. Second, authority as in the workplace or at school or any other places that requires the practice of social life may prescribe it. The point to be noted here is that although following appropriate etiquette may not be required, but to do so shall put the person with the groups that have "good breading". Reversing the definition will put it like this: not following etiquette will put the individual outside of the good breeding groups.

Different words have been also used to describe etiquette. For example, cultural norms are used synonymously to describe the etiquette practiced within a particular culture. Also, protocols are used to describe the etiquette of introduction to new culture such as the introduction of foreign credentials. At the same time, other words like manners, conventions are also used to replace the word etiquette in many instances (Perry, 2012). Some take it a step further and equate etiquette with good manners [14].

\section{Etiquette - Development and Importance}

Norms, including rules of etiquette, are learned through experience in a community. For example, children observe how adults and other children behave, absorb these norms, and learn their community's etiquette at an early age. This role-modeling process continues throughout life. Other community members correct those who do not conform to expectations. Problems arise when people go into other cultures with different norms, particularly when the differences are subtle [19, P. 58].

The development of etiquette begins typically at home. When children grow up, they learn what is appropriate and what is not appropriate by observing and following their parents and relatives. But during the development process, children face different cultures and may move from one community to another whether by choice or by necessity. In each new culture, there will be new sets of etiquette that needs to be learned in order to adapt to the new culture. Take for example; going from elementary to high school, the children undoubtedly face new set of etiquette that forces a new learning process. Another example is the case when moving to a new community that introduces new learning of etiquettes of the new culture.

The importance of following the etiquette of a culture varies depending on the involvement of the people in the culture. At times, not following etiquette may produce simple embarrassment, but at others it may produce arguments, inconvenience and even cultural clashes.

Preece (2004) gives an example of such embarrassing situation for gift giving in the Japanese culture as compared to American culture. In the American culture, if a person receives a gift, the etiquette suggests that that the person opens the gift, shows admiration for the gift and thanks the other person for it. In the Japanese culture, it is the opposite; a person receiving a gift should hold it, take it home and open it at a later stage. Opening the gift in front of the person is considered rude in the Japanese culture. 


\section{Issues in Information Systems}

Volume 14, Issue 2, pp.452-462, 2013

Breaking the rules of etiquette sometimes may create more than a simple embarrassment; it may create clashes, arguments and even more. Langford (2005) described an incident that he witnessed at a restaurant. Following completing his meal, one customer paid the bill and added a tip for the cashier. The customer then angrily yelled at the cashier for not thanking him for the tip. The cahier in turn followed the customer arguing that the customer is the one who is rude because he gave him such a small tip.

\section{e-Etiquette}

The word e-Etiquette refers to the etiquette developed from using the electronic devices for communication purposes. This may refer to etiquettes for using the Internet, email, chat sessions, and communication over other electronic devices such as cell phones.

The importance of E-etiquette continues to grow and there is more calls for developing and following such etiquettes. Preece (2004) noted "Etiquette online is not just nice to have, it is necessary" (P. 56). Initial use of Internet was limited to certain people that have the knowledge and the mean to connect to the Internet. As the use of the Internet increased, so did the variety of people using it and the problem associated with communicating over the Internet. Subsequent developments led to the call for developing etiquette for exchanging emails, chat sessions and also to include such etiquette in the development of educational technology courses [15].

\section{Community of Practice (COP)}

The community of practice refers to people working together or working in the same environment [7]. The workplace is one such place of community of practice and the taking courses at a college or university is another example. Following etiquette (or e-etiquette) plays more significance in such communities than in casual contacts as described in the examples above. Another author called the etiquette in such places as "The Unspoken Rules for Business Success" [11, p. 56]. It further clarifies that learning about the etiquettes of the workplace gives an edge in terms of hiring, promotion, getting clients and many other incidents.

\section{The Teaching of Etiquette and e-Etiquette}

Most contend that etiquette is learned through experience. The question that asks itself is whether there is necessary to teach etiquette for a workplace, a college or a course. More particular, the question can be asked about the etiquettes of using cell phones in the classroom, whether it is better to teach the etiquette or leave it the students to learn about it from their interactions with the classes and courses they take. The answer is more directly moving toward the necessity of teaching etiquettes for many reasons, listed some below.

Langland (2009) explained about the importance of teaching e-Etiquette at colleges and universities and noted that one of the difficulties of adjusting to the workplace is that new graduates are not familiar with enforcement of using cell phones. In other words, students at colleges in most cases have freedom of using their cell phones anytime anywhere they want to. As they start working, they are faced with many rules regarding the timing and places for using cell phone. Langland (2009) said "New college graduates used to texting and checking Facebook during class should be aware of policies regarding the personal use of the Internet and electronic devices in the workplace (P. 37). Leland (2005) noticed that increasing number of managers do get irritated when during meeting for example, a cell phone rings and one of the employees pick up the phone - all while the meeting is going on.

Kolb (2011) noted that most students are not aware of the negative effects that cell phones have on the class and suggested educating the students of such effects. In another study [16] that surveyed students about their use of cell 


\section{Issues in Information Systems \\ Volume 14, Issue 2, pp.452-462, 2013}

phones in the classroom noted that about $45 \%$ of the students surveyed thought that the instructor do not know that the students are using cell phones in the class.

The author's opinion is that it is beneficial to teach the students about the etiquette/e-etiquette of use cell phones and other devices in the classroom. Such teaching will benefit the students and may help to limit the distractions of their use. However, in order to give useful evidence about the distractions of cell phone, some information about the misuse and proper use of cell phones in the classroom is helpful. The next section explains about the misuse and distractions of cell phones in the classroom. The following section discusses using cell phones for learning and educational activities.

\section{Cell Phones in the Classroom - Misuses and Distractions}

The common consensus among educators is that student cell phone use in the classroom distracts from learning [16] [6]. This is echoed in various literature and statistics, much of which is cited in this paper. The two figures below, downloaded from Google's web site, exemplify typical misuse of cell phone on the classroom. Figure 3 shows a student talking on the cell phone not paying attention to the lecture. Figure 4 shows one student using a cell phone while the other student is distracted by this use.

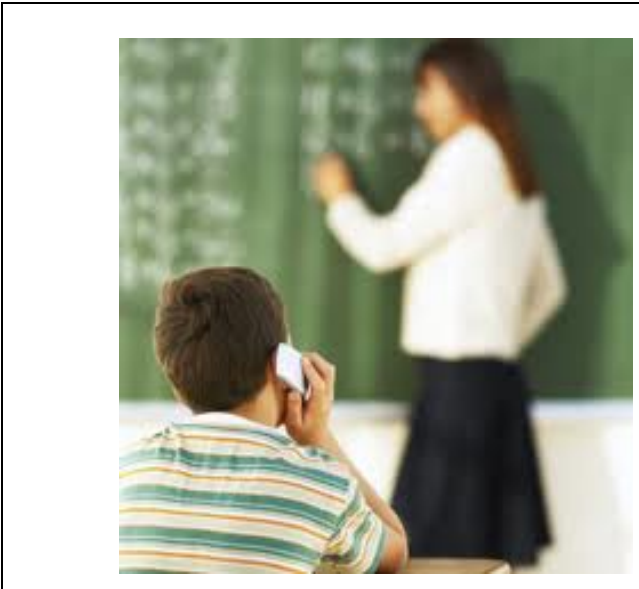

Figure 4 - Cell phone use in class disrupts a lecture.

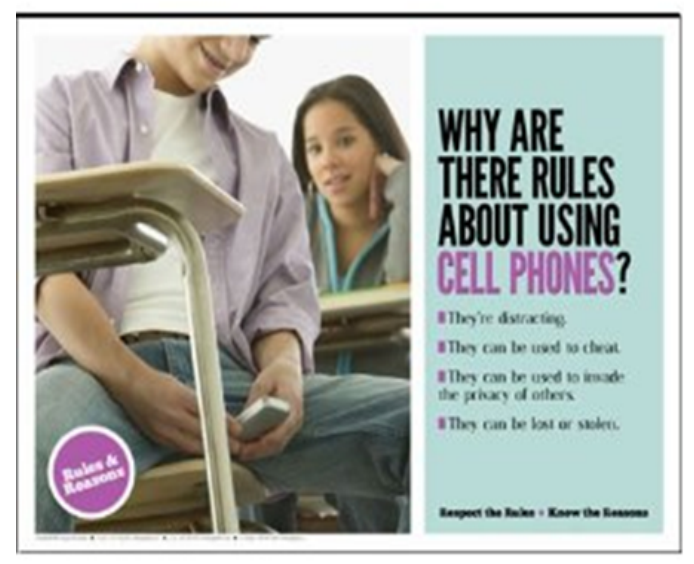

Figure 5 - Distraction by Cell Phone Use 1

The remainder of this section discusses these two opposite points of view. It begins by first explaining the misuse of cell phones in the classroom, and then it continues, explaining how some faculty have more recently been using cell phones in the classroom for educational and learning purposes.

\section{The Misuse of Cell Phones}

The most reported forms of cell phone misuse in the classroom include: texting, cheating, sexting, playing games, and other forms of misuse[3]. Although some of these misuses may be deemed appropriate in other instances, doing the same act in the classroom is considered distracting and disrupting.

The most common occurrence of cell phone misuse in the classroom is texting, or sending text messages, often during a lecture. Sending text messages is becoming one of the easiest things to do with cell phones. According to Tindell and Bohlander (2012), more than $90 \%$ of students sent text messages during classes. Technology made it much easier to send and receive messages in a very short time through cell phones. A student may do this silently -type a message and send it, all within a few seconds, while holding the cell phone under a keyboard tray or under a 


\section{Issues in Information Systems \\ Volume 14, Issue 2, pp.452-462, 2013}

desk. With the help of short message services (SMS) and predictive text, SMS messages can be written quickly, even in your pocket (Prensky, 2004). Bugeja (2007) reported on a 16-year-old and her friends who text each other continuously during class and other times when they should be studying. As technology evolves, texting often includes sending and receiving photos or videos to each other as well.

Cheating using cell phones is reported differently. The most common form of cheating using cell phones is done during exams. Tindell and Bohalander (2012) reported a concern about academic dishonesty. One example took place at a university where 12 students were caught cheating during an accounting exam. Students outside the test, with access to the answer key, texted the answers to multiple choice exam questions to students taking the exam. At another university, 11 nursing students admitted cheating on an exam by texting the questions to students who had already completed the test. Technology made it easier to silently capture an image of the exam through cell phones, send them to friends and then receive the answers in a short time span [23].

Sexting in this context refers to sending or receiving sexually suggestive images or text via text messaging. This may include sexual comments via text messages, nude photos or any other distribution of documents within sexual contexts. According to Kolb (2011), sexting is common among college students and that the majority of students have received some form of sexual content images/messages through their cell phones in one form or another. But in this context, the issue is that with sending/receiving these kinds of images during class. Receiving these images is often followed by sharing the photo or text with other students, which has a ripple effect on the class. Playing games is reported also as one of the misuses of cell phones during class. Once again, technology has made it easier to play games without being noticed by others.

\section{The Distractions}

According to Tindell \& Bohlander (2012) and Kolb (2011), most students do not know that their use of cell phones in the classroom causes distractions to others. But, it does. It causes distractions to the student who is using it, it causes distractions to the other students in the class (especially who are sitting nearby), and it causes distractions to the teacher as well [23]. The remainder of this section elaborates on each of these distractions caused by the use of cell phones in the classroom.

In regards to the distraction that cell phone use brings to the student using it, the logical perception about cell phone use is that if the student is using the cell phone during a lecture, then the student is not paying attention, and he/she will be at a disadvantage. But, this is not only a perception; it is supported by different studies that point to the distractions caused by cell phones as a reason that puts the students at a disadvantage.

Pottharst (2010) reported on a student in the class receiving a message from his girlfriend. After checking it and going back to class, he found himself lost and did not know what is going on in the lecture. This typical situation takes place every day when students get distracted by their cell phones. Bugeja (2007) reports on a teacher who had students using cell phones in the classroom. After the teacher started a policy banning cell phones in the classroom, grades improved. The teacher attributed the lower grades to the distractions caused by using the cell phones.

Shelton et al (2009) conducted an investigative study on the distracting effects of a ringing cell phone. The study found the students implicated by the ringing phone were the most affected by the ringing tone. Gilroy (2004) noted that this happens very often: a student sitting in the class waiting for a phone call, and explained that it is "too much of a temptation and a distraction to be waiting for a call to pay attention to what is happening in class" P. 58 .

\section{Distraction to the other students in the classroom}




\section{Issues in Information Systems}

Volume 14, Issue 2, pp.452-462, 2013

The students using cell phones may not be aware of the distraction that their cell phone cause to other students in the classroom. Burns and Lohenry (2010) conducted a pilot study to determine the effects of cell phone use in the classroom and noted that about $45 \%$ of the students admitted using cell phones in the classroom, which caused distractions for about $85 \%$ of the students. Pottharst (2010) reports that cell phones distract $89 \%$ of students during study hours and nearly $77 \%$ of students during class. The distractions that Pottharst explains do not necessarily involve receiving unexpected phone calls, but also texting, browsing on Facebook, checking emails and other distractions.

The ringing cell phones cause the most obvious distraction to others. If the student picking up the phone and then walking out follows that, this may cause more distractions. Probably, the most severe effect of using cell phones in the classroom is the distraction that it causes to the teacher. This is true because if the teacher gets distracted, all of the class will be affected, because the teaching attention is often shifted to the distraction that the ringing cell phone caused. Gilroy (2004) calls this the "the teaching moment" and expressed strong opinion about it:

It is the most common (and unsettling) occurrences in today's classrooms - the ringing of a cell phone, often punctuated by some silly tune or sound that announces to everyone that a call is coming in. Inevitably, educators say, it happens during an important part of a lecture or a discussion, just when a critical point is being made, suddenly, the 'teachable moment' is lost.

But a ringing cell phone is not the only way that the use of cell phones distracts teachers. Students holding their cell phone under the desks while texting, browsing, reading emails, or playing games may attract the attention of and become a distraction to him/her. What follows may lead to more distraction and more loss of "teaching moments". A teacher may ask the student to put the cell phone away or take any action, then the student may deny use, and it may lead to tense moments that affect the entire class.

Technology has made it difficult for teachers to distinguish whether or not students are using their cell phones for class purposes. Students often use their cell phones for browsing the electronic textbook that they purchased for class. At the same time, they may be playing games. It is hard to distinguish. In large classes or classrooms that have too many barriers (like computer monitors) this will be more difficult to distinguish. Faculty in these cases are put in difficult positions trying to determine whether a student is playing a game with the cell phone or browsing the Kindle edition of the textbook.

\section{Cell Phone in the Classroom - Appropriate Uses}

The increasing capabilities of cell phones are forcing educators to rethink about using them in the classroom. This coupled with the ease of use at which cell phone application usage are becoming made some educators advocate using them as tools for educational and learning purposes. The two figures below show this shift in trend about educator's thinking of cell phones in the classroom. Figure 5 shows this shift in thinking about cell phone use. Figure 6 suggests that there is 29 ways to productive use of cell phones in the classroom. 


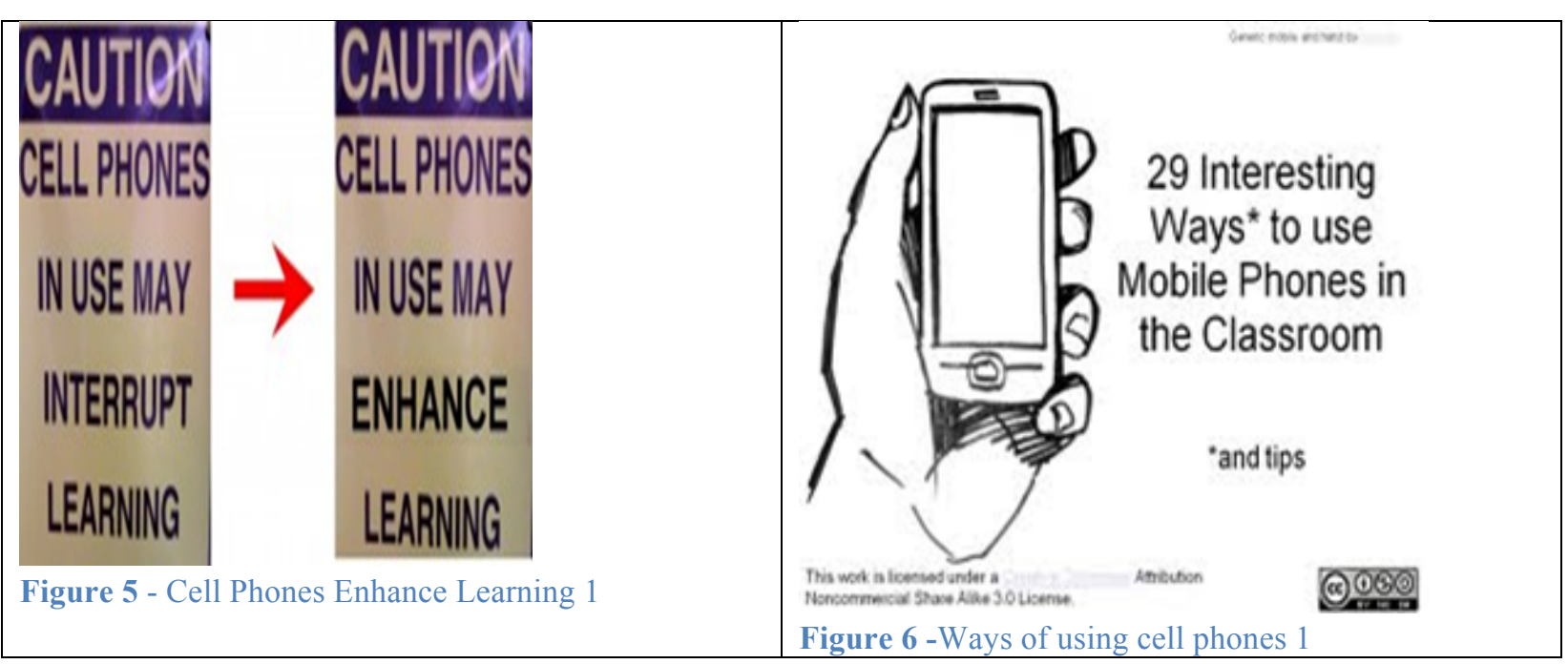

The remainder of this section explains about what can be learned from cell phones and suggestions for practical application of cell phones in the classroom.

\section{What Can be Learned from Cell Phones}

Can cell phones really provide their owners with the knowledge, skills, behaviors and attitudes that will help them succeed in their schools, their jobs and their lives? I maintain the only correct answer to "What they can learn" question is "ANYTHING, if we design it right". There are many different kinds of learning and many processes that we use to learn, but among the most frequent, time-tested, and effective of these are listening, observing, imitating, questioning, reflecting, trying, estimating, predicting, "what-if" ing practicing. All of these learning processes can be done through our cell phones. In addition, the phones compliment the short-burst, casual, multi-tasking of today's "digital Native Learners" [20, P. 3].

The literature reviewed in this study shows that there are many ways to integrate cell phones into courses for academic and learning purposes. Armario (2009) reported on a Spanish teacher who welcomes using cell phones in the classroom. "Spanish vocabulary becomes a digital scavenger hunt. Notes are copied with a cell phone camera. Text messages serve as homework reminders." (p. 1). Bernard (2012) reported on English teachers taking text messaging to task as a teaching tool to "Tame Texting" in the classrooms.

\section{Practical Application of Cell Phones in the Classroom}

Kolb (2011) noted several useful applications of cell phones in the classroom but emphasized that there will be some rules that govern the use of cell phones in the classroom. Among the applications suggested for inclusion in the cell phones include:

- Reminders for students about deadlines

- Browsers for search engines

- Cameras for scientific data collection

Prensky (2004) advocated using the many features of cell phones to enhance learning through the use of:

- Voice only, used for timely reminders of deadlines 


\section{Issues in Information Systems}

Volume 14, Issue 2, pp.452-462, 2013

- $\quad$ Short Text Messages (SMS) for learning reminders and encouragements

- Graphic display and animation such as those used for anatomy forensics

- Downloadable programs for collaboration purposes

- Internet browsers, through which students may use the many web sites specifically designed for cell phone applications, such as a dictionary, search for images, search engines and others

- Cameras, cell phones with cameras are tools for scientific data collection, documentation, and visual journalism

- Global Positioning Systems, available on many cell phones, allow them to be "learning specific". The location specifically allows them to be used for topics like geography, orientation or archeology

- Video clips, short video clips extend learning capabilities into television journalism and movie making

\section{TEACHING THE ETIQUETTE OF CELL PHONE USE IN THE CLASSROOM}

A faculty at a University located in Western Pennsylvania has been dealing with the issue of cell phone use in the classroom for several years with limited success. Students were using cell phones in the classroom at different times. This faculty tried at various times using a soft approach [1]) in dealing with this use of cell phones. He tried to stare at the students using the cell phones or try to make jokes about using cell phones. The same faculty often directly speaks to particular students who are using the phone and ask them not to use the cell phones during lecture. This also had little success because most of the classes that this faculty teaches are taught in computer labs in large classroom. The size of the classroom and the availability of computers in front of the students make it easier for the students to hide the cell phones under the keyboard. These facts coupled with the increasing use of cell phones for learning activities made this faculty focus instead on teaching the students the etiquette of using cell phones in the classroom.

The faculty started teaching the etiquette and e-etiquette of cell phone use in the classroom in one-hour lecture and walks the students through some of what is explained earlier in this paper. The remainder of this section explains what is taught in this one-lecture

\section{Cell Phones in the Classroom - Misuses and Distractions}

The lesson begins by explaining the many ways of misusing the cell phones. It illustrates the misuses by showing images that depicts such misuse. It focuses on the many distractions that cell phone use causes to the class, including the student himself/herself, the surrounding students and the faculty. The lecture explains stresses that the distraction caused to the instructor will ultimately affects the entire class because it hinders his ability to focus on the lecture.

\section{Cell Phone in the Classroom - Appropriate Uses}

The lesson then continues to show the appropriate uses and the practical applications of using cell phones for learning and educational purposes. It asks the students to use the cell phone for learning activities for the class only. If they need to take emergency call, the can ask to be excused and take it out of the classroom.

\section{Summary of Rules}

At the end of the lesson the faculty shows a table summarizing the rules about the use of cell phones in the classroom. This summary is shown in table 1 listed below:

$$
\text { Table } 1 \text { - Rules about Using Cell Phones in the Classroom }
$$

\begin{tabular}{|l|l|l}
\hline Misuse of Cell Phone (not allowed) & Appropriate Use (Allowed) & Ask Permission or Leave Class
\end{tabular}




\begin{tabular}{|lr|l|l|}
\hline Texting & & Calendar & Taking Emergency Call \\
Sexting & Games & Anything Other use & \\
Playing & SMS for learning reminders and \\
Browsing & Web & & \\
Using the Camera & the & & \\
\hline
\end{tabular}

\section{Enforcement Policy}

In addition to the summary table and the instructions given, the faculty added the following clause to the syllabus for his courses:

The use of cell phones or similar electronic devices (such as IPOD, MP3 players, DVD player or similar) is not allowed during the class. This includes during lecture time, the working on assignment time as well as the time waiting for instructions. Students violating this role for the first time will be asked to turn their device off. If violation occurs more than once students will be recorded absent for the class.

The author had problems with enforcing this rule for a number of reasons. First, all the students that were asked about their use of cell phone they respond that they are either handling emergency or they are using it for classroom purposes. Second, it will be difficult to verify their improper use because further questioning the students about their misuse may violate their privacy [24] and creates more problems than it solves. Nevertheless, the faculty decided to keep such clause in the syllabus hoping that it will discourage some students from improperly using cell phones in the classroom.

\section{CONCLUSIONS}

This paper discussed teaching the etiquette of using cell phone in the classroom. It began by explaining about etiquette, e-etiquette and the different terminologies associated with them. It then explained about the improper uses of cell phones and followed that by explanation of the practical application and proper of cell phones in the classroom. The author then talked about his experience of dealing with cell phones use in the classroom and how he teaches the etiquette of using cell phones in the classroom.

The teaching of etiquette for this faculty is something new, thus the effectiveness of this teaching is yet to be determined. The author intends to conduct a follow-up study to measure the effectiveness of his teaching of etiquette. Such a study will use a survey to ask the students about their view of the etiquette and whether it helped cutting down the misuse of cell phone in the classroom. It will also address the difficulty with enforcing policies restricting the use of cell phones in the classroom.

\section{REFERENCES}

1. Ali, A. I., Papakie, M., \& McDevitt, T. (2012). Dealing with the Distractions of Cell Phone Misuse/Use in the Classroom - A Case Example. Competition Forum, 10(2), 220-230.

2. Armario, C., (2009, November 28). Classrooms welcome cell phone use. The Wichita Eagle. Retrieved July 22, 2012 from http://www.kansas.com/2009/11/28/1074447/classrooms-welcome-cell-phone.html .

3. Bugeja, M. J. (2006). Facing the Facebook. Chronicle of Higher Education, 52 (21), C1-C4.

4. Bugeja, M.J. (2007). Distractions in the Wireless Classroom. Chronicle Of Higher Education, 53(21), C1-C4.

5. Burns, S. M., \& Lohenry, K. (2010). Cellular phone use in class: Implications for teaching and learning a pilot study. College Student Journal, 44(3), 805-810.

6. Campbell, S. (2006). Perceptions of mobile phones in college classrooms: Ringing, cheating, and classroom policies. Communication Education, 55(3), 280-294.

7. Claudia, C., Motta, C., Santoro, F. \& Marcos, E. (2009). Applying Reputation Mechanisms in Communities of Practice: A Case Study. Journal of Universal Computer Science, vol. 15, no. 9 (2009), 1886-1906. 


\section{Issues in Information Systems}

Volume 14, Issue 2, pp.452-462, 2013

8. Etiquette (2013). In Merriam-Webster.com. Retrieved January 20, 2013 from http://www.merriamwebster.com/dictionary/etiquette

9. Gilroy, M. (2004). Invasion of the classroom cell phones. Education Digest, 69 (6), 56-60.

10. Kolb, L. (2011). Cell Phones in the classroom: A Practical Guide for Educators. Eugene, OR: International Society for Technology in Education.

11. Langford, B. Y. (2005). The Etiquette Edge: The Unspoken Rules for Business Success. Amacom Books.

12. Langland, M. (2009). Evolving e-Etiquette in the Workplace. National Association of Colleges and Employees Journal, March 2009, 37-40.

13. Leland, J. (2005, July 7). Just a Minute Boss, My Cell Phone Is Ringing. The New York Times, July 7, 2005,

14. Ling, R. S. (2008). New tech, new ties: how mobile communication is reshaping social cohesion. Cambridge, MA: MIT Press

15. Mishra, P., \& Hershey, K. A. (2004). Etiquette and the design of educational technology. Communications of the $A C M, 47(4), 45-49$.

16. Obringer, S.J., \& Coffey, K. (2007). Cell phones in American high schools: A national survey. Journal of Technology Studies, 33(1), 41-47.

17. Perry, C. (2012). Nursing Ethics and Etiquette. The American Journal of Nursing, 6 (7), 448-452.

18. Pottharst, S. (2010, January 20). Cell phones: A classroom distraction. The Daily Campus, Wednesday January 20, 2010. Retrieved -July 18, 2012 from http://www.smudailycampus.com/news/cell-phones-a-classroomdistraction-1.1079676.

19. Preece, J. (2004). Etiquette online: from nice to necessary. Communications of the ACM, Volume 47 Issue 4. $56-61$.

20. Prensky, M., (2004). What can you learn from a cell phone? Retrieved from http://www.marcprensky.com/writing/prensky-what can you learn from a cell phone-final.pdf

21. Shelton, J. T., Eliott, E., M., Eaves, S, D., \& Exner, A. L (2009). The distracting effects of a rnigning cell phones: An Investigation of the laboratory and the classroom setting. Journal of Environmental Psychology, 29, 513-521.

22. Tindell, D. R., \& Bohlander, R. W. (2012). The use and abuse of cell phones and text messaging in the classroom: A survey of college students. College Teaching, 60(1), 1-9. doi:10.1080/87567555.2011.604802

23. Wei, F., \& Wang, Y. (2010). Students' silent messages: Can teacher verbal and nonverbal immediacy moderate student Use of text messaging in class?. Communication Education, 59(4), 475-496.

24. Wei, R., Leung, L. (1999). Blurring Public and Private Behaviors in Public Space: Policy Challenges in the Use and Improper use of the Cell Phone. Telematics and Informatics 16, 11-26. 